\title{
KUALITAS PELAYANAN PENDIDIKAN PADA MASA PANDEMI COVID-19 PROGRAM STUDI TADRIS KIMIA FAKULTAS TARBIYAH DAN KEGURUAN UIN ANTASARI BANJARMASIN
}

\author{
Ardian Trio Wicaksono \\ Program Studi Tadris Kimia, FTK, Universitas Islam Negeri Antasari Banjarmasin \\ ardian.tw@uin-antasari.ac.id \\ Dewi Purboningsih \\ Program Studi Administrasi Publik, FISIP, Universitas Lambung Mangkurat Banjarmasin \\ dewi.purboningsih@ulm.ac.id
}

\begin{abstract}
Abstrak
Pandemi Covid-19 telah mengubah berbagai macam tatanan kehidupan, termasuk dalam pendidikan dari secara langsung menjadi online. Pelayanan pendidikan yang dilakukan secara langsung tentu berbeda dengan kualitas pelayanan yang dilakukan secara online yang dirasakan oleh mahasiswa selaku pengguna pelayanan pendidikan. Kualitas pelayanan pendidikan yang ingin diketahui difokuskan terhadap 3 bidang yakni bidang informasi, bimbingan dan kesejahteraan. Bidang informasi meliputi informasi lisan dan informasi tertulis. Bidang bimbingan meliputi akademik, mengatasi kesulitan belajar, mengatasi masalah pribadi, pendidikan dan pengajaran serta praktik keilmuan. Bidang kesejahteraan meliputi pemberian beasiswa dan keringanan uang kuliah tunggal. Berdasarkan kondisi tersebut, tujuan dari penelitian ini untuk mengetahui kualitas pelayanan pendidikan pada masa pandemi Covid-19 Program Studi Tadris Kimia pada bidang informasi, bimbingan dan kesejahteraan dan faktor faktor yang mempengaruhinya. Jenis penelitian yang dilakukan adalah penelitian lapangan menggunakan pendekatan kualitatif. Teknik pengumpulan data dilakukan dengan menggunakan wawancara secara online melalui google meet. Hasil penelitian menunjukkan bahwa kualitas pelayanan pendidikan pada bidang informasi, bimbingan dan kesejahteraan tergolong baik dan terdapat berbagai faktor yang mempengaruhinya.
\end{abstract}

Kata Kunci: kualitas, pelayanan pendidikan, masa pandemi.

\begin{abstract}
The Covid-19 pandemic has changed various kinds of life, including in education from in-person to online. Education services that are carried out directly are certainly different from the quality of services carried out online which are felt by students as users of educational services. The quality of educational services that we want to know is focused on 3 areas, namely the fields of information, guidance and welfare. The field of information includes oral information and written information. The field of guidance includes academics, overcoming learning difficulties, overcoming personal problems, education and teaching and scientific practice. The welfare sector includes the provision of scholarships and single tuition waivers. Based on these conditions, the purpose of this study was to determine the quality of educational services during the Covid-19 pandemic of the Chemistry Tadris Study Program in the fields of information, guidance and welfare and the factors that influence it. The type of research conducted is field research using a qualitative approach. Data collection techniques were carried out using online interviews via google meet. The results showed that the quality of education services in the fields of information, guidance and welfare was good and there were various factors that influenced it.
\end{abstract}

Keywords: quality, education services, pandemic period.

\section{PENDAHULUAN}

Selama hampir dua tahun ini pandemi Covid-19 terjadi di sebagian besar wilayah dunia, tidak terkecuali Indonesia. Pandemi ini mengubah seluruh tatanan kehidupan manusia dan berdampak pada berbagai macam sektor, termasuk sektor pendidikan. Pernyataan ini sesuai dengan yang disampaikan oleh Perserikatan Bangsa 
Bangsa atau PBB yang menyatakan bahwa salah satu sektor yang terdampak adanya wabah ini adalah dunia Pendidikan (Purwanto dkk, 2020:1).

Layanan pendidikan merupakan salah satu bentuk pelayanan publik. Hal ini sesuai dengan Undang-undang RI No. 25 Tahun 2009 pasal 1 ayat 1 berbunyi: pelayanan publik adalah kegiatan atau rangkaian kegiatan dalam rangka pemenuhan kebutuhan pelayanan sesuai dengan kebutuhan perundangundangan bagi setiap warga negara dan penduduk atas barang, jasa dan/atau pelayanan administratif yang disediakan oleh penyelenggara pelayanan publik. Layanan pendidikan di sekolah sebagai layanan publik dinyatakan dalam pasal 5 ayat 2 UU No. 25 Tahun 2009 tentang pelayanan publik yang selengkapnya berbunyi: ruang lingkup sebagaimana dimaksud pada ayat 2 meliputi pendidikan, pengajaran, pekerjaan dan usaha, tempat tinggal, komunikasi dan informasi, lingkungan hidup, kesehatan, jaminan sosial, energi, perbankan, perhubungan, sumberdaya alam, pariwisata, dan sektor strategis lainnya.

Layanan pendidikan yang biasanya dilakukan secara langsung melalui pertemuan tatap muka di kelas kelas, saat ini ditiadakan. Hal tersebut dilakukan untuk mengantisipasi atau meminimalisir terjadinya penyebaran virus Covid-19 yang sangat cepat menular antar manusia salah satunya melalui droplet dari batuk atau bersin (Huang C, 2020). Kondisi ini menuntut para pemangku kebijakan untuk mencari solusi agar layanan pendidikan tetap dapat terlaksana di masa pandemi, salah satunya dengan mengeluarkan Surat Edaran Kementerian Pendidikan dan Kebudayaan (Kemendikbud) Direktorat Pendidikan Tinggi No. 1 Tahun 2020 mengenai pencegahan penyebaran Covid-19 di dunia Pendidikan. Edaran tersebut menginstruksikan bahwa pelayanan pendidikan dilakukan secara online. Pelayanan online adalah sistem pelayanan yang dilakukan dengan memanfaatkan bantuan teknologi berupa internet tanpa bertatap muka secara langsung. Internet telah dipadukan menjadi sebuah alat yang digunakan untuk melengkapi aktivitas pembelajaran (Martins,2015).

Mahmud (2012) menyebutkan bahwa secara umum terdapat 6 layanan pendidikan yang dapat dilakukan oleh instansi pendidikan. Layanan tersebut berupa layanan informasi, layanan sarana prasarana, layanan administrasi, layanan bimbingan, layanan pengembangan bakat dan minat serta keterampilan, dan layanan kesejahteraan. Berbagai bentuk layanan tersebut perlu dilakukan untuk memberikan kepuasan terhadap pengguna yang terdiri atas siswa ataupun mahasiswa. Pelayanan pendidikan yang dilakukan secara langsung tentu berbeda dengan kualitas pelayanan yang dilakukan secara online yang dirasakan oleh mahasiswa selaku pengguna pelayanan pendidikan. Adanya pandemi Covid-19 mengakibatkan terjadinya perbedaan teknis layanan dari secara langsung menjadi online ini dapat berdampak pada kualitas layanan pendidikan yang dirasakan oleh mahasiswa Program Studi Tadris Kimia. Pada penelitian ini kualitas layanan pendidikan yang ingin diteliti berpusat terhadap 3 bidang yang berhubungan langsung dengan Program Studi Tadris Kimia.yakni bidang informasi, bidang bimbingan dan bidang kesejahteraan.

Layanan informasi adalah layanan yang memungkinkan siswa menerima dan memahami berbagai informasi seperti informasi pendidikan dan informasi jabatan yang dapat digunakan sebagai bahan pertimbangan dan pengambilan keputusan untuk kepentingan siswa (Winkel, 2012). Layanan informasi yang disampaikan dapat berupa informasi secara lisan atau informasi secara tertulis. Layanan bimbingan diawali dengan program orientasi sekolah, bimbingan dalam mengatasi kesulitankesulitan khususnya kesulitan belajar dan juga masalah-masalah pribadi, bimbingan pendidikan dan pengajaran (KBM), dan bimbingan praktik keilmuan. Selain itu, di antara bentuk pelayanan lainnya terdapat layanan kesejahteraan kepada siswa berupa pemberian beasiswa kepada siswa yang berprestasi khususnya kalangan kurang mampu serta pemberian keringanan SPP (Mahmud, 2012). 


\section{METODE}

Jenis penelitian yang dilakukan oleh peneliti adalah penelitian lapangan yang bertujuan untuk mengetahui kualitas pelayanan pendidikan pada masa pandemi Covid-19 Program Studi Tadris Kimia pada bidang informasi, bimbingan dan kesejahteraan. Penelitian ini menggunakan pendekatan kualitatif dengan memaparkan fakta yang terjadi dan selajutnya dideskripsikan. Data yang akan diteliti dalam penelitian ini terdiri atas data kualitas pelayanan pendidikan pada masa pandemi Covid-19 Program Studi Tadris Kimia pada bidang informasi, bimbingan dan kesejahteraan serta data faktor faktor yang mempengaruhi kualitas pelayanan pendidikan pada masa pandemi Covid-19 Program Studi Tadris Kimia pada bidang informasi, bimbingan dan kesejahteraan.

Sumber data dalam penelitian ini adalah mahasiswa program studi tadris kimia angkatan 2017-2021 sebagai pengguna pelayanan pendidikan bidang informasi, bimbingan dan kesejahteraan. Teknik pengumpulan data menggunakan wawancara yang dilakukan secara online melalui media google meet. Pertanyaan yang diajukan berkaitan dengan pelayanan pendidikan pada 3 bidang yakni bidang informasi meliputi informasi lisan dan informasi tertulis; bidang bimbingan meliputi akademik, mengatasi kesulitan belajar, mengatasi masalah pribadi, pendidikan dan pengajaran serta praktik keilmuan; bidang kesejahteraan meliputi pemberian beasiswa dan keringanan uang kuliah tunggal.

Data yang diperoleh dalam penelitian ini dianalisis menggunakan teknisk deskriptif kualitatif yang terdiri atas beberapa tahap yakni reduksi, display dan verifikasi. Tahap reduksi dilakukan untuk mengetahui kualitas pelayanan pendidikan pada masa pandemi Covid-19 Program Studi Tadris Kimia dan faktor faktor yang mempengaruhinya. Tahap display dilakukan untuk merangkum informasi yang diperoleh dan disusun secara sistematis sehingga tujuan penelitian dapat diketahui dengan mudah. Tahap verifikasi dilakukan untuk memberikan makna yang sesuai terhadap simpulan yang akan ditentukan.

\section{HASIL DAN PEMBAHASAN}

Pelayanan pendidikan memegang peranan penting dalam mengembangkan dan meningkatkan kualitas sumber daya manusia. Pandemi Covid-19 berdampak pada perubahan bentuk pelayanan pendidikan yang awalnya bertatap muka menjadi pelayanan berbasis online di berbagai instansi termasuk perguruan tinggi di Indonesia, salah satunya adalah Program Studi Tadris Kimia UIN Antasari Banjarmasin sebagai penyedia layanan pendidikan. Penelitian ini dilaksnaakan dengan melakukan wawancara online kepada mahasiswa Tadris Kimia UIN Antasari untuk mengetahui kualitas layanan pendidikan yang berhubungan langsung dengan Program Studi Tadris Kimia yakni layanan informasi, layanan bimbingan dan layanan kesejahteraan serta faktor faktor yang mempengaruhinya, untuk selanjutnya dipaparkan dalam penjelasan berikut sesuai hasil penelitian yang diperoleh.

\section{Kualitas Pelayanan Pendidikan Bidang Informasi dan Faktor yang Mempengaruhinya}

Layanan informasi saat pandemi seperti sekarang ini menjadi salah satu hal yang penting untuk diketahui melalui penelitian yang dilakukan baik layanan lisan maupun layanan tertulis. Pertama, kualitas layanan informasi akademik secara lisan (tatap muka secara langsung atau melalui telpon) yang dilakukan oleh prodi selama masa pandemi berdasarkan hasil wawancara dapat dikategorikan dalam beberapa kategori. Beberapa alasan yang disampaikan oleh mahasiswa merupakan faktor faktor yang mempengaruhi kualitas layanan informasi akademik selama masa pandemi. Terdapat sembilan orang mahasiswa menyampaikan bahwa layanan informasi akademik dalam bentuk lisan yang dilakukan oleh prodi selama masa pandemi sudah cukup baik. Hal ini dikarenakan, beberapa mahasiswa belum pernah melaksanakan perkuliahan secara tatap muka khususnya pada mahasiswa baru. Selanjutnya, terdapat dua puluh tiga orang mahasiswa menyampaikan bahwa layanan 
informasi secara lisan yang dilakukan oleh prodi selama masa pandemi sudah baik. Hal tersebut karena prodi selalu tanggap dan cepat merespon dalam layanan informasi baik melalui chat ataupun telepon; prodi memberikan layanan informasi tepat waktu dan informasi yang diberikan mudah dipahami dengan jelas. Terdapat sepuluh orang mahasiswa menyampaikan bahwa layanan informasi secara lisan yang dilakukan oleh prodi selama masa pandemi sudah sangat baik dan sangat memuaskan. Hal tersebut karena prodi selalu memberikan informasi akademik secara cepat; mengingatkan kembali informasi kepada mahasiswa; informasi diberikan penjelasan secara detail; dan prodi juga bersedia melayani informasi secara tatap muka dengan memperhatikan protokol kesehatan.

Berdasarkan hasil penelitian diketahui bahwa kualitas pelayanan pendidikan bidang informasi secara lisan dalam kategori baik meskipun dilakukan melalui pembelajaran jarak jauh. Penyampaian informasi secara lisan melalui bantuan berbagai media teknologi seperti smartphone dan aplikasi lainnya misalnya zoom meeting dan google meet masih efektif dilakukan selama masa pandemi untuk meminimalisir penyebaran virus Covid-19. Hal ini sesuai dengan kebijakan UNESCO yang memberikan dukungan penuh kepada negara-negara di seluruh dunia, untuk melakukan proses pembelajaran jarak jauh yang sifatnya inklusif sebagai solusinya (Huang, Yang, Tlili, \& Chang, 2020).

Kedua, layanan informasi akademik yang diberikan prodi secara tertulis yang dibagikan melalui grup Whatsapp selama pandemi, berdasarkan hasil wawancara dapat dikategorikan dalam berbagai faktor yang mempengaruhi kualitas layanan informasi akademik secara tertulis. Terdapat satu orang mahasiswa yang memberikan penilaian kurang baik pada layanan informasi akademik secara tertulis. Hal ini dikarenakan, informasi yang disampaikan melalui chat Whatsapp sulit dimengerti karena informasi tertumpuk dengan beberapa pesan chat yang lainnya. Selanjutnya, terdapat tiga puluh dua orang mahasiswa menyampaikan bahwa layanan informasi akademik secara tertulis yang diberikan oleh prodi sudah baik. Hal tersebut karena prodi selalu tanggap memberikan informasi; dosen sangat mudah untuk dihubungi; dosen maupun prodi memberikan informasi secara jelas; prodi selalu up to date dalam memberikan informasi; dan penyampaian informasi secara tertulis mudah dipahami oleh mahasiswa. Selain itu, terdapat sembilan orang mahasiswa memberikan penilaian dalam layanan informasi secara tertulis sangat bagus atau sangat baik.Menurut beberapa mahasiswa tersebut, bahwa informasi yang disampaikan oleh prodi melalui pesan Whatsapp sangat membantu mahasiswa; dan bapak atau ibu dosen juga sering mengingatkan kembali informasi yang berkaitan dengan akademik; serta prodi dan dosen cepat dan tanggap merespon pertanyaan pertanyaan dari mahasiswa.

Selain penyampaian informasi secara lisan, informasi juga dapat disampaikan secara tertulis melalui berbagai macam aplikasi yang sudah tersedia pada smartphone. Salah satu aplikasi yang saat ini efektif digunakan dalam menyampaikan informasi tertulis adalah whatsapp baik secara individu maupun dalam grup. Hasil penelitian menunjukkan bahwa penyampaian informasi secara tertulis yang dilakukan selama ini melalui whatsapp berada dalam kategori baik. Berdasarkan hasil penelitian ini dapat diketahui bahwa whatsapp dapat digunakan sebagai salah satu sarana dalam menyampaikan informasi tertulis serta pembelajaran secara online/daring. Hal ini sesuai dengan hasil penelitian yang dilakukan oleh Rasmitadila dkk. (2020) melalui risetnya menemukan bahwa WhatsApp telah digunakan dalam pembelajaran daring.

\section{Kualitas Pelayanan Pendidikan Bidang Bimbingan dan Faktor yang Mempengaruhinya}

Hasil penelitian terkait kualitas pelayanan pendidikan bidang bimbingan memuat beberapa aspek yang dilakukan selama masa pandemi yakni program bimbingan akademik, bimbingan mengatasi kesulitan belajar, bimbingan mengatasi masalah pribadi, bimbingan pendidikan dan 
pengajaran (KBM), dan bimbingan pelaksanaan praktikum.

Pertama, kualitas layanan bimbingan akademik yang dilakukan oleh prodi selama masa pandemi berdasarkan hasil wawancara dapat dikategorikan dalam beberapa kategori. Beberapa alasan yang disampaikan oleh mahasiswa merupakan faktor faktor yang mempengaruhi kualitas layanan bimbingan akademik selama masa pandemi. Terdapat tiga orang mahasiswa menyampaikan bahwa layanan bimbingan akademik yang dilakukan oleh prodi selama masa pandemi sudah cukup baik. Hal tersebut karena pernah terjadi misskomunikasi antara mahasiswa dengan dosen pembimbing akademik. Terdapat tiga orang mahasiswa menyampaikan bahwa layanan bimbingan akademik yang dilakukan oleh prodi selama masa pandemi sudah cukup baik. Terdapat dua puluh tujuh orang mahasiswa menyampaikan bahwa layanan bimbingan akademik yang dilakukan oleh prodi selama masa pandemi sudah baik. Hal tersebut karena prodi selalu tanggap dalam layanan tersebut baik melalui chat ataupun telepon; prodi memberikan bimbingan dengan baik; tidak dipersulit walau masa pandemi; bimbingan bisa dilakukan kapan saja di hari kerja; mengikuti alur yang seharusnya; dosen penasihat merespon dengan cepat; dapat meningkatkan pengetahuan akakdemik; bisa menanyakan melalui WA; dan membantu saya dalam mengatasi masalah perkuliahan. Terdapat dua belas orang mahasiswa menyampaikan bahwa layanan bimbingan akademik yang dilakukan oleh prodi selama masa pandemi sudah sangat baik. Hal tersebut karena dosen semangat dalam membimbing mahasiswa; dapat melakukan konsultasi secara online dan juga respon yang cepat; walaupun online bimbingan akademik masih bisa terlaksana; layanan bimbingan sangat membantu mahasiswa; dan dosennya sangat loyal untuk melakukan bimbingan.

Layanan bimbingan akademik merupakan bagian dari proses pembelajaran bagi mahasiswa selama menempuh pendidikan di perguruan tinggi. Hasil penelitian menunjukkan bahwa layanan bimbingan akademik tergolong baik meskipun dalam masa pandemi. Hal ini menunjukkan bahwa prodi tetap berusaha memberikan pelayanan secara maksimal selama pandemi secara online sebagai bentuk dukungan terhadap kebijakan pemerintah. Adanya kebijakan tersebut memunculkan luaran bahwa semua institusi pendidikan tidak melakukan kegiatan belajar mengajar seperti biasanya, sehingga dapat mengurani efek penyebaran penyakit Covid19 (Wargadinata dkk, 2020).

Kedua, kualitas layanan bimbingan mengatasi kesulitan belajar yang dilakukan oleh prodi/dosen selama masa pandemi berdasarkan hasil wawancara dapat dikategorikan dalam beberapa kategori. Beberapa alasan yang disampaikan oleh mahasiswa merupakan faktor faktor yang mempengaruhi kualitas layanan bimbingan mengatasi kesulitan belajar selama masa pandemi. Terdapat satu orang mahasiswa menyampaikan bahwa layanan bimbingan mengatasi kesulitan belajar yang dilakukan oleh prodi selama masa pandemi kurang baik. Hal tersebut karena media pembelajaran yang digunakan ada yang tidak sesuai dengan kehendak mahasiswa, seperti penggunaan LMS dari kampus yang agak ribet karena dalam pengumpulan tugasnya, ukuran file dibatasi dan harus memasukkan sandi/pasword terlebih dahulu sebelum masuk tidak seperti google classroom yang lebih praktis. Tetapi sebenarnya beberapa mata kuliah ada juga yang menggunakan google classroom. Terdapat sembilan orang mahasiswa menyampaikan bahwa layanan bimbingan mengatasi kesulitan belajar yang dilakukan oleh prodi selama masa pandemi sudah cukup baik. Hal tersebut karena kadang terkendala karena jaringan; koutanya lelet; dan bisa teratasi dengan baik. Terdapat dua puluh empat orang mahasiswa menyampaikan bahwa layanan bimbingan mengatasi kesulitan belajar yang dilakukan oleh prodi selama masa pandemi sudah baik. Hal tersebut karena dosen selalu siap menanggapi keluhan mahasiswa; dosen menjelaskan materi, mengadakan sesi tanya jawab dan bertanya kepada mahasiswa untuk mengetahui apakah mahasiswa itu sudah paham atau belum; dosen/prodi tanggap dalam menangani masalah mahasiswa; 
dosen/prodi memberikan solusi untuk mengatasi kesulitan dalam proses pembelajaran; pembelajaran dapat dilakukan ketika pandemi; konsultasi dapat langsung di kampus dan bisa juga melalui chat; dapat membuat saya tertarik untuk mengikuti pembelajaran; dan selalu ada saran saran yang diberikan sehingga bisa mengambil keputusan. Terdapat delapan orang mahasiswa menyampaikan bahwa layanan bimbingan mengatasi kesulitan belajar yang dilakukan oleh prodi selama masa pandemi sudah sangat baik. Hal tersebut karena bapak ibu dosennya asik buat curhat; dapat memaklumi mahasiswa; dan memberikan solusi kepada saya saat mengatasi kesulitan-kesulitan.

Kesulitan belajar yang dialami mahasiswa akibat peralihan dari pembelajaran secara langsung menjadi pembelajaran secara online merupakan hal yang wajar dan dapat dimaklumi pada masa transisi akaibat pandemi. Prodi dan dosen berusaha mengatasi kesulitan belajar yang dihadapi mahasiswa. Dampaknya kualitas pelayanan kesulitan belajar berada dalam kategori baik. Mahasiswa membutuhkan waktu untuk beradaptasi terhadap berubahnya sistem pembelajaran agar meminimalisir terjadinya kendala atau kesulitan belajar yang dialami mahasiswa selama proses belajar diawal pandemi. Hal ini sesuai dengan hasil penelitian Kharisma (2020) yang menyatakan bahwa kegiatan belajar melalui pembelajaran daring selama masa belajar di rumah pada hari-hari pertama diterapkannya sistem pembelajaran daring, tidak pelak banyak kendala terutama bagi yang belum pernah melakukannya.

Ketiga, kualitas layanan bimbingan mengatasi masalah pribadi (kesulitan kuota internet atau kesulitan membayar Uang Kuliah Tunggal (UKT) dll) yang dilakukan oleh prodi selama masa pandemi berdasarkan hasil wawancara dapat dikategorikan dalam beberapa kategori. Beberapa alasan yang disampaikan oleh mahasiswa merupakan faktor faktor yang mempengaruhi kualitas layanan bimbingan mengatasi masalah pribadi (kesulitan kuota internet atau kesulitan membayar UKT dll) selama masa pandemi. Terdapat tiga orang mahasiswa menyampaikan bahwa layanan bimbingan mengatasi masalah pribadi (kesulitan kuota internet atau kesulitan membayar UKT dll) sudah cukup baik. Hal tersebut karena mahasiswa kurang mengetahui. Terdapat dua puluh lima orang mahasiswa menyampaikan bahwa layanan bimbingan mengatasi masalah pribadi (kesulitan kuota internet atau kesulitan membayar UKT dll) sudah baik. Hal tersebut karena alhamdulillah dapat bantuan kuota internet; dosen selalu menginformasikan program beasiswa dan kouta gratis di grup jurusan; dosen/prodi tanggap dalam menangani hal tersebut; prodi memberikan layanan bimbingan masalah pribadi dengan baik; terdapat solusi dari dosen pembimbing akademik; alhamdulillah masalah ini sudah ditangani dengan baik dengan memberikan bantuan kuota dan keringanan UKT oleh pihak kampus; mendapatkan kuota untuk belajar; prodi memberikan informasi terkait pengurangan UKT dll; ada bantuan untuk kuota internet dan pengurangan UKT; selalu ditanya terkait kelancaran proses pembelajaran, apabila ada permasalahan selalu dicari jalan keluar bersama; adanya kouta gratis jadi mempermudah; mendapat keringanan; layanan bimbingan mahasiswa didengarkan oleh pihak prodi; memberikan keringanan waktu, ataupun membantu masalahnya; dan disediakan link pendaftaran bantuan kuota. Terdapat empat belas orang mahasiswa menyampaikan bahwa layanan bimbingan mengatasi masalah pribadi (kesulitan kuota internet atau kesulitan membayar UKT dll) sudah sangat baik. Hal tersebut karena alhamdulillah saya rutin mendapatkan bantuan kuota internet perbulan; selalu membantu memberikan informasi; sekarang uin memberikan kuota gratis sehingga meminimalisir pengeluaran selama pandemi; bisa memahami kondisi mahasiswa; masalah terkait kesulitan kuota dan kesulitan pembayaran UKT diselesaikan dengan informasi-informasi yang diberikan prodi terkait keringanan pembayaran UKT dan bantuan kuota; pada masa pendemi mahasiswa diberi kemudahan dalam pembelajaran seperti adanya program kouta gratis dan juga dapat mengajukan perpanjangan waktu pembayaran UKT dan juga pengurangan UKT; diberikan solusi; 
dengan adanya layanan bimbingan mahasiswa akan terbantu; diberi kelonggaran untuk mengurus hal hal tersebut; dan biasanya banyak sekali diberikan info mengenai kouta dan lain lain.

Kesulitan lain yang dihadapi oleh mahasiswa adalah kesulitan masalah pribadi (kesulitan kuota internet atau kesulitan membayar UKT dll). Hal ini sedikit teratasi dengan adanya bantuan dari pemerintah melalui Universitas terkait kuota internet bagi mahasiswa dan dosen serta keringan membayar UKT baik dari sisi biaya dan perpanjangan waktu pembayaran. Kuota internet sangat membantu dalam pembelajaran secara daring seperti saat ini. Di sisi lain, pembelajaran secara daring juga menimbulkan berbagai kendala misalnya jaringan. Hal ini membuat mahasiswa merasa bosan dan kurang berminat pada pembelajaran daring yang sudah hampir dua tahun ini. Hal ini sejalan dengan pendapat Setyowahyudi \& Ferdiyanti (2020) yang menyatakan bahwa beberapa kendala yang ada dalam pembelajaran daring membuat para peserta didik kurang berminat terhadap pembelajaran daring tersebut. Berdasarkan hasil penelitian diketahui bahwa kualitas layanan bimbingan mengatasi masalah pribadi yang dilakukan oleh prodi dan dosen berada dalam kategori baik.

Keempat, kualitas layanan pendidikan dan perkuliahan yang dilakukan oleh prodi selama masa pandemi berdasarkan hasil wawancara dapat dikategorikan dalam beberapa kategori. Beberapa alasan yang disampaikan oleh mahasiswa merupakan faktor faktor yang mempengaruhi kualitas layanan pendidikan dan perkuliahan selama masa pandemi. Terdapat dua orang mahasiswa menyampaikan bahwa layanan pendidikan dan perkuliahan yang dilakukan oleh prodi selama masa pandemi kurang baik. Hal tersebut karena beberapa mata kuliah praktikum dilaksanakan secara daring yang dimana hal tersebut menjadikan mahasiswa bingung dalam melaksanakan praktikum; merasa bosan dalam hal online dan itu membuat probadi saya menjadi malas, semoga secepatnya bisa diadakan offline seperti yang diinginkan. Terdapat delapan orang mahasiswa menyampaikan bahwa layanan pendidikan dan perkuliahan yang dilakukan oleh prodi selama masa pandemi sudah cukup baik. Hal tersebut karena perkuliahan terasa sulit, interaksi dosen dan mahasiswa kadang terkendala sinyal; kurang memahami, soalnya terbiasa dijelaskan secara langsung bukan melalui gmeet dkk; kalau bisa menggunakan pesan suara atau tatap muka menggunakan meet atau zoom, kalau lewat pesan terkadang susah dimengerti; perkuliahan dilaksanakan seperti biasanya; ada beberapa dosen yang hanya memberikan kuliah melalui tugas dan di chat saja. Terdapat dua puluh empat orang mahasiswa menyampaikan bahwa layanan pendidikan dan perkuliahan yang dilakukan oleh prodi selama masa pandemi sudah baik. Hal tersebut karena dosen masuk tepat waktu, dan media pembelajarannya pun bervariasi seperti WA group, clasroom, dan juga google meet; akan lebih bagus lagi jika perkuliahan dilakukan secara offline dengan mematuhi protokol kesehatan; perkuliahan dapat dilakukan dengan lancar; selalu diusahakan dengan profesional; dapat meningkatkan belajar karena dengan adanya belajar online; rata rata selama pandemi dosen masuk selalu memberikan tugas; google classroom bisa menyimpan semua pelajaran; lumayan membuat saya paham mengenai materi perluasan; dan alhamdulillah perkuliahan terlaksana dengan efektif dan efesien. Terdapat delapan orang mahasiswa menyampaikan bahwa layanan pendidikan dan perkuliahan yang dilakukan oleh prodi selama masa pandemi sudah sangat baik. Hal tersebut karena kualitas yang diberikan dosen sudah sangat baik; dosen/prodi tanggap dalam menangani hal tersebut; tidak dipersulit bahkan jauh lebih fleksibel; dan dosen berusaha semaksimal mungkin dengan segala hambatan selama pandemi ini.

Kualitas layanan pendidikan dan perkuliahan yang dilakukan oleh prodi selama masa pandemi berada dalam kategori baik. Layanan pendidikan dan perkuliahan tetap dijalankan dengan baik oleh para tenaga pengajar secara daring melalui berbagai media dan teknologi seperti pembuatan video pembelajaran yang diupload melalui youtube, penggunaan google classroom, google meet, zoom meeting dan LMS (Learning Management 
System). Dengan memanfaatkan mekanisme pembelajaran daring, guru dapat mengembangkan pembelajaran kreatif dan baru yang memanfaatkan sumber daya daring sebagai media sebagai pembelajaran berbasis multimedia interaktif dan media pembelajaran berbasis personal blog oleh guru (Argaheni, 2020).

Kelima, kualitas layanan konsultasi judul proposal yang dilakukan oleh prodi selama masa pandemi berdasarkan hasil wawancara dapat dikategorikan dalam beberapa kategori. Beberapa alasan yang disampaikan oleh mahasiswa merupakan faktor faktor yang mempengaruhi kualitas layanan konsultasi judul proposal selama masa pandemi. Terdapat tujuh orang mahasiswa menyampaikan bahwa layanan konsultasi judul proposal yang dilakukan oleh prodi selama masa pandemi kurang baik. Hal tersebut karena belum pernah mengajukan proposal. Terdapat tiga orang mahasiswa menyampaikan bahwa layanan konsultasi judul proposal yang dilakukan oleh prodi selama masa pandemi sudah cukup baik. Hal tersebut karena ada dosen yang cepat dan lambat dalam membalas chat konsultasi. Terdapat dua puluh satu orang mahasiswa menyampaikan bahwa layanan konsultasi judul proposal yang dilakukan oleh prodi selama masa pandemi sudah baik. Hal tersebut karena dosen tanggap dalam melayani hal tersebut; sering mengkonsultasikan judul proposal dengan dosen pengampu mata kuliah metodologi pendidikan; terkadang fast respon, terkadang slow respon, dan saya juga memaklumi dikarenakan dosen mempunyai kesibukannya masing-masing; dosen pembimbing selalu ada; konsultasi judul dapat dilakukan; dan diberi bimbingan yang baik. Terdapat sebelas orang mahasiswa menyampaikan bahwa layanan konsultasi judul proposal yang dilakukan oleh prodi selama masa pandemi sudah sangat baik. Hal tersebut karena dosennya selalu memberikan masukan; dosen penasihat akademik semangat sehingga mahasiswa juga semangat; diberi kemudahan dalam berkonsultasi secara online, dan juga respon yang sangat cepat dari dosen penasehat akademik mampu membuat mahasiswa mudah dalam mengerjakan proposal; prodi mendukung seratus persen mahasiswanya lulus tepat waktu, bukan hanya mendukung namun benar-benar membantu mencarikan solusi; dan dosen memberikan saran saran untuk judul judul terbaru.

Keenam, kualitas layanan bimbingan skripsi yang dilakukan oleh prodi selama masa pandemi berdasarkan hasil wawancara dapat dikategorikan dalam beberapa kategori. Beberapa alasan yang disampaikan oleh mahasiswa merupakan faktor faktor yang mempengaruhi kualitas layanan bimbingan skripsi selama masa pandemi. Terdapat lima belas orang mahasiswa menyampaikan bahwa layanan bimbingan skripsi yang dilakukan oleh prodi selama masa pandemi kurang baik. Hal tersebut karena tidak tahu; belum pernah melakukan konsultasi skripsi; dan belum sampai pada tahap bimbingan skripsi. Terdapat dua orang mahasiswa menyampaikan bahwa layanan bimbingan skripsi yang dilakukan oleh prodi selama masa pandemi sudah cukup baik. Hal tersebut karena ada dosen yang cepat dan lambat dalam membalas chat konsultasi. Terdapat lima belas orang mahasiswa menyampaikan bahwa layanan bimbingan skripsi yang dilakukan oleh prodi selama masa pandemi sudah baik. Hal tersebut karena dosen dengan tanggap melayani mahasiswa yang sedang bimbingan skripsi; bisa dilakukan secara online, walau juga ada yang offline; dan prodi serta dosen memberikan layanan bimbingan skripsi dengan baik. Terdapat sepuluh orang mahasiswa menyampaikan bahwa layanan bimbingan skripsi yang dilakukan oleh prodi selama masa pandemi sudah sangat baik. Hal tersebut karena setiap mahasiswa yang ingin melakukan bimbingan selalu dilayani secara tatap muka maupun melalui telpon ataupun chat whatsapp; diberi kemudahan dalam berkonsultasi dengan cara konsul secara online, dan juga respon yang sangat cepat dari dosen penasehat akademik mampu membuat mahasiswa mudah dalam mengerjakan proposal; dosen bersedia melayani mahasiswa setiap minggu untuk bimbingan; dosen pembimbing memberikan bimbingan dengan sangat baik; dan dosen sangat fast respond.

Layanan konsultasi judul proposal dan bimbingan skripsi tetap diberikan oleh dosen 
selama masa pandemi. Pelayanan biasanya dilakukan secara langsung di kampus dengan membawa print out naskah, selama pandemi pelayanan dilakukan secara daring melalui file sehingga bersifat paperless. Pelayanan ini berada dalam kategori baik karena semua pihak berkomitmen melayani mahasiswa dalam konsultasi judul proposal maupun bimbingan skripsi. Mahasiswa dan dosen berusaha menyesuaikan kondisi melalui penggunaan teknologi sesuai perkembangan zaman saat ini agar proses konsultasi judul proposal maupun bimbingan skripsi tetap berjalan lancar pada masa pandemi. Anak didik dituntut menguasai teknologi, kreatif, memiliki motivasi dan gairah belajar yang tinggi, mampu melakukan inovasi dengan target mempersiapkan milenial dalam menghadapi tantangan di era global (Fauzi \& Khusuma, 2020).

Ketujuh, kualitas layanan pelaksanaan praktikum yang dilakukan oleh prodi selama masa pandemi berdasarkan hasil wawancara dapat dikategorikan dalam beberapa kategori. Beberapa alasan yang disampaikan oleh mahasiswa merupakan faktor faktor yang mempengaruhi kualitas layanan pelaksanaan praktikum selama masa pandemi. Terdapat delapan orang mahasiswa menyampaikan bahwa layanan pelaksanaan praktikum yang dilakukan oleh prodi selama masa pandemi kurang baik. Hal tersebut karena belum pernah praktikum; dari segi keterampilan dan pengalaman sebagian besar kurang bermakna bagi mahasiswa; materi praktikum cenderung sulit dimengerti ketika daring; tidak melaksanakan praktikum secara langsung di laboratorium; dan hanya dilakukan secara online, hanya ada satu praktikum yang dilaksanakan offline, itupun juga baru beberapa kali pertemuan. Terdapat sepuluh orang mahasiswa menyampaikan bahwa layanan pelaksanaan praktikum yang dilakukan oleh prodi selama masa pandemi sudah cukup baik. Hal tersebut karena sedikit ada rasa risih karena sebagian besar cuma berupa pengumpulan laporan, harapannya jurusan mengusahakan praktikum offline di laboratorium; walaupun praktikum seadanya di rumah tidak di laboratorium; kurang interaksi dengan alat alat laboratorium karena pandemi; praktikum diadakan di rumah masing masing dengan bahan sekitar; selama masa pandemi masih bisa melakukan praktikum walaupun dengan paraktikum sederhana, dan tidak dilakukan diilaboratorium; praktikum hanya dilakukan secara online; hanya melalui video saja dan melakukan praktikum yang mudah di rumah dengan alat seadanya; dan jarang ada praktikum saat pandemi. Terdapat dua puluh empat orang mahasiswa menyampaikan bahwa layanan pelaksanaan praktikum yang dilakukan oleh prodi selama masa pandemi sudah baik. Hal tersebut karena ada beberapa dosen yang mengarahkan mahasiswa untuk melakukan praktikum berbasis potensi lokal, sehingga mahasiswa tetap merasakan praktikum walaupun sedang pandemi. Tetapi ada juga dosen yang tidak memberikan vidio percobaan sehingga mahasiswa tidak mengetahui proses praktikum tersebut; penyampaian sudah baik meskipun praktikum online memerlukan waktu yang panjang untuk memahaminya; layanan yang diberikan bagus, namun sulit dipahami karena dilakukan secara daring; prodi dan dosen memberikan layanan pelaksanaan praktikum dengan baik; sudah baik, namun lebih baik lagi jika praktikum dilaksanakan secara offline walaupun pada mata kuliah lain masih online; bagus, tetapi akan lebih bagus lagi jika pelaksanaan praktikum di lakukan secara offline. Dikarenakan mahasiswa kurang paham dengan pelaksanaan praktikum yang dilakukan secara online dan bingung dengan praktikum yang dilakukan; belum bisa dilakukan sepenuhnya, hanya bisa dilakukan di rumah; alhamdulillah selalu ada sarana kedua untuk mengatasi praktikum di situasi daring; dapat mengasah keterampilan melalui praktikum; hanya bisa mengajarkan dan melihat alatnya; dan alhamdulillah sudah mulai belajar di lab dan semoga dalam ketertinggalan ini tidak menyulitkan kami untuk praktikumpraktikum untuk semester selanjutnya.

Berdasarkan hasil penelitian dapat diketahui bahwa selama pandemi proses pembelajaran praktikum dapat terlaksana dengan baik, menggunakan alat dan bahan sederhana yang berada di sekitar rumah. Pelaksanaan praktikum di laboratorium 
untuk sementara ditiadakan sebagai antisipasi penyebaran virus Covid-19. Hal ini sesuai dengan hasil penelitian yang dilakukan oleh Herliandry dkk, 2020) yang menyatakan bahwa solusi yang bisa dilakukan yakni dengan memberlakukan proses pembelajaran di dalam rumah dengan memanfaatkan berbagai macam fasilitas pendukung yang mendukung proses tersebut.

\section{Kualitas Pelayanan Pendidikan Bidang Kesejahteraan dan Faktor yang Mempengaruhinya}

Layanan kesejahteraan saat pandemi dilaksanakan dalam dua kegiatan. Pertama, kegiatan pemberian beasiswa kepada mahasiswa berprestasi dan mahasiswa kurang mampu. Kedua, kegiatan pemberian informasi keringanan UKT. Kualitas layanan kesejahteraan yang dilakukan oleh prodi selama masa pandemi berdasarkan hasil wawancara dapat dikategorikan dalam beberapa faktor. Beberapa alasan yang disampaikan oleh mahasiswa merupakan faktor faktor yang mempengaruhi kualitas layanan kesejahteraan selama masa pandemi.

Pertama, layanan kesejahteraan dalam bentuk pemberian informasi beasiswa kepada mahasiswa berprestasi dan kurang mampu, terdapat satu orang mahasiswa menyampaikan penilaian kurang baik. Menurut mahasiswa tersebut, informasi terkait beasiswa perlu ditingkatkan dan ada pendampingan bagi mahasiswa yang berprestasi. Selain itu, terdapat dua orang mahasiswa menyampaikan dalam layanan kesejahteraan dalam informasi beasiswa yang dilaksanakan oleh prodi cukup baik. Selanjutnya, terdapat tiga puluh tiga orang mahasiswa memberikan pendapat bahwa pelayanan kesejahteraan dalam kegiatan pemberian informasi beasiswa yang dilaksanakan oleh prodi sudah baik. Adapun penilaian yang dikuatkan dengan berbagai penjelasan bahwa layanan informasi beasiswa yang sangat cepat, prodi selalu membagikan informasi tersebut melalui grup WA. Bahkan, prodi juga memberikan bimbingan bagi mahasiswa yang berhak mendapatkan beasiswa. Tambahan pula, ada enam mahasiswa yang memberikan penilaian terhadap layanan kesejahteraan dalam pemberian informasi beasiswa sangat bagus dan memuaskan. Dalam hal ini, prodi bergerak cepat dan memudahkan mahasiswa dalam menyiapkan berkas dokumen persyaratan untuk memperoleh beasiswa prestasi maupun beasiswa kurang mampu.

Kedua, layanan kesejahteraan dalam bentuk pemberian informasi keringanan UKT (Uang Kuliah Tunggal). Dalam hal ini, terdapat lima orang mahasiswa memberikan penilaian cukup baik yang diperkuat dengan alasan prosedur mendapatkan keringanan UKT lumayan ribet. Akan tetapi, ada dua puluh delapan orang mahasiswa menyampaikan penilaian bahwa layanan informasi keringan UKT sudah baik. Tambahan lagi, sembilan orang mahasiswa memberikan penilaian terhadap prodi dalam pelayanan tersebut sangat baik atau bagus. Hal ini diperkuat dari penjelasan mahasiswa bahwa layanan pemberian informasi keringanan UKT telah disampaikan dengan baik; sangat cepat memberikan informasi; sangat membantu mahasiswa dan orang tua dalam masa pandemi; bahkan prodi juga mengkonfirmasi kembali informasi tersebut kepada mahasiswa.

Kesehatan merupakan salah satu sektor penting yang ditangani secara serius saat pandemi Covid-19 ini. Selain itu, terdapat banyak sektor yang lainnya yang juga merasakan dampak pandemi, sektor tersebut adalah sektor ekonomi dan sektor pendidikan. Banyak orang yang mengalami pemutusan hubungan kerja serta banyak anak usia sekolah yang memutuskan untuk berhenti sekolah karena terkendala biaya. Pemerintah melalui pimpinan Universitas selaku pemangku kebijakan berusaha meminimalisir kejadian ini dengan memberikan bantuan kesejahteraan bagi mahasiswa melalui beasiswa dan keringanan pembayaran UKT. Hal ini tentu disambut baik oleh banyak pihak termasuk orang tua agar pendidikan anaknya tetap bisa berjalan. Kesejahteraan mahasiswa akan berdampak pada motivasi belajar, prestasi belajar dan perilaku mahasiswa selama mengikuti pembelajaran. Memahami faktor kesejahteraan sekolah bermanfaat untuk membantu pemangku kepentingan dalam menentukan strategi meningkatkan 
kesejahteraan sekolah karena kesejahteraan sekolah merupakan faktor yang berpengaruh terhadap motivasi belajar siswa (Rachmah, 2016), prestasi belajar (Alsa et al., 2015), menurunkan perilaku negatif siswa seperti agresivitas (Nidianti \& Desiningrum, 2015). Kualitas layanan kesejahteraan yang dilakukan oleh dosen dan prodi berada dalam kategori baik. Dosen dan prodi berusaha menyampaikan informasi terkait beasiswa dan keringanan UKT kepada mahasiswa dengan cepat.

\section{DAFTAR PUSTAKA}

Alsa, A., Haq, A. H. B., Siregar, A. J., Kusumaningrum, F. A., Utami, H. D., \& Bachria, R. D. 2015. Menyusun model yang efisien dan efektif dari dimensi-dimensi school wellbeing untuk memprediksi prestasi belajar matematika. Jurnal Psikologi, 42(1), 15. (https://doi.org/10.22146/jpsi.6940, diakses 4 Oktober 2021).

Argaheni, N. B. 2020. Sistematik review: Dampak perkuliahan daring saat pandemi COVID-19 terhadap siswa Indonesia. Placentum: Jurnal Ilmiah Kesehatan dan Aplikasinya, 8(2), 99109.

(https://jurnal.uns.ac.id/placentum/artic le/view/43008/28002, diakses 7 Oktober 2021).

Fauzi, I., \& Khusuma, I. H. S. 2020. Teachers' elementary school in online learning of COVID-19 pandemic conditions. Jurnal Iqra': Kajian Ilmu Pendidikan, 5(1), 58-70. (https://journal.iaimnumetrolampung.a c.id/index.php/ji/article/view/914/512, diakses 5 Oktober 2021).

Herliandry, L. D., Nurhasanah, N., Suban, M. E., \& Kuswanto, H. 2020. Pembelajaran pada masa pandemi COVID-19. Jurnal Teknologi Pendidikan, 22(1), 65-70. (http://journal.unj.ac.id/unj/index.php/j tp/article/view/15286/8695, diakses 6 Oktober 2021).

Huang, R., Yang, J., Tlili, A., \& Chang, T. W. (2020). Handbook on facilitating flexible learning during educational disruption: The Chinese experience in

\section{SIMPULAN}

Berdasarkan hasil penelitian dan pembahasan, maka diperoleh simpulan bahwa kualitas pelayanan pendidikan pada masa pandemi Covid-19 Program Studi Tadris Kimia Fakultas Tarbiyah dan Keguruan UIN Antasari Banjarmasin tergolong baik. Kualitas pelayanan dilakukan pada bidang informasi, bimbingan dan kesejahteraan.

maintaining undisrupted learning in COVID-19 outbreak. Beijing: Smart Learning Institute of Beijing Normal University. (https://iite.unesco.org/wpcontent/uploads/2020/03/Handbookon-Facilitating-Flexible-Learning-inCOVID-19-Outbreak-SLIBNU-V1.220200315.pdf, diakses 6 Oktober 2021).

Huang C, Wang Y, Li X, dkk. Gambaran klinis pasien yang terinfeksi coronavirus novel 2019 di Wuhan, Cina [koreksi yang dipublikasikan muncul di Lancet. 202030 Januari]. Lanset. 2020; 395 (10223): 497-506. (DOI:10.1016/S0140-6736(20)301835, diakses 7 Oktober 2021).

Kharisma, N. N. 2020. Gambaran kebutuhan pembelajaran daring PKBM Budi Utama Surabaya. Jurnal Pendidikan Non Formal, 15(1), 38-44. (http://journal2.um.ac.id/index.php/JP N/article/view/15174/6073, diakses 9 Oktober 2021).

Martins, M. de L. 2015. How to Effectively Integrate Technology in the Foreign Language

Classroom for Learning and Collaboration. Procedia - Social and Behavioral Sciences. Vol. 174, Halm. 77-84. (https://www.sciencedirect.com/scienc e/article/pii/S1877042815006801, diakses 8 Oktober 2021).

Marzuki Mahmud. 2012. Manajemen Mutu Perguruan Tinggi. Jakarta: PT Raja Grafindo Persada.

Nidianti, W. E. \&, \& Desiningrum, D. R. (2015). Hubungan antara school wellbeing dengan agresivitas. Empati: 
Jurnal Karya Ilmiah S1 Undip, 4(1), 202-207.

(https://ejournal3.undip.ac.id/index.ph p/empati/article/view/13141, diakses 9 Oktober 2021).

Purwanto dkk. 2020. Studi Eksploratif Dampak Pandemi COVID-19 Terhadap Proses Pembelajaran Online di Sekolah Dasar. Journal of Education, Psychology, and Counselling. Volume 2 No. 1. (https://ummaspul.ejournal.id/Edupsycouns/article/view/39 7/223, diakses 11 Oktober 2021).

Rachmah, E. N. 2017. Pengaruh school well being terhadap motivasi belajar siswa. Personifikasi Jurnal Ilmu Psikologi, Vol 8, No 1. (https://journal.trunojoyo.ac.id/personi fikasi/article/view/3853/2818, diakses 10 Oktober 2021).

Rasmitadilla, R., Aliyyah, R. R., Rachmadtullah, R., Samsudin, A., Syaodih, E., Nurtanto, M., \& Tambunan, A. R. S. 2020. The perceptions of primary school teachers of online learning during the COVID19 pandemic period: A case study in Indonesia. Journal of Ethnic and Cultural Studies, 7(2), 90-109. (http://www.ejecs.org/index.php/JECS/ article/view/388/pdf, diakses 12 Oktober 2021).
Setyowahyudi, R., \& Ferdiyanti, T. 2020. Keterampilan guru PAUD Kabupaten Ponorogo dalam memberikan penguatan selama masa pandemi COVID-19. Jurnal Golden Age, 4(1), 100-112. (https://ejournal.hamzanwadi.ac.id/index.php/jg a/article/view/2167/1284, diakses 12 Oktober 2021).

Kemendikbud. 2020. Surat Edaran Kementerian Pendidikan dan Kebudayaan (Kemendikbud) Direktorat Pendidikan Tinggi No. 1 Tahun 2020. (https://covid19.hukumonline.com/wpcontent/uploads/2020/04/surat_edaran_ direktur_jenderal_pendidikan_tinggi_n omor_1_tahun_2020-2.pdf, diakses 13 Oktober 2021).

Wargadinata, W., Maimunah, I., Dewi, E. \& Rofiq, Z .2020. Student's responses on learning in the early COVID-19 Pandemic. Jurnal Keguruan dan Ilmu Tarbiyah, 5 (1), 141-153. (http://ejournal.radenintan.ac.id/index. php/tadris/article/view/6153/pdf, diakses 13 Oktober 2021).

Winkel. 2012. Bimbingan dan Konseling di Institut Pendidikan. Yogyakarta: Media Abadi. 